\title{
Hookworm-related cutaneous larva migrans acquired in the UK
}

\author{
Katy Baple, James Clayton
}

Department of Microbiology, Royal Surrey County Hospital, Guildford, UK

\section{Correspondence to Dr Katy Baple, katy.baple@nhs.net}

Accepted 28 October 2015

\section{SUMMARY}

Hookworm-related cutaneous larva migrans ( $\mathrm{HrCLM}$ ) is a skin disease caused by infection with the larvae of animal hookworms. With conditions for infection more favourable in tropical climates, HrCLM in the UK is classically diagnosed in the returning traveller. We present two cases of clinically diagnosed UK-acquired HrCLM from a district general hospital in the south of England. A 68-year-old woman presented with a pruritic serpiginous tract on the right hand. She was a keen gardener and had been handling compost. A 50-year-old man, a long distance runner, presented with a similar lesion on the dorsum of his foot. Both patients were treated with a single dose of albendazole. These cases may represent an emerging infection in the UK. In the absence of a suggestive travel history, early recognition followed by efficient access to therapy is vital for treating HrCLM transmitted in the UK.

\section{BACKGROUND}

Hookworm-related cutaneous larva migrans (HrCLM) is a skin disease caused by infection with the larvae of animal hookworms, particularly those that infect cats and dogs. Species include Ancylostoma braziliense and Ancylostoma caninum. With conditions for infection more favourable in tropical or subtropical climates, HrCLM in the UK is classically diagnosed in the returning traveller. However, cases acquired within the UK are reported. The clinical history and examination findings of a classic serpiginous erythaematous lesion known as a 'creeping eruption' resulting from the migrating larvae are fundamental to forming the diagnosis.

We report two cases of clinically diagnosed UK-acquired HrCLM presenting to a district general hospital in the south of England in the summer of 2014.

\section{CASE PRESENTATION}

\section{Case 1}

A 68-year-old woman presented with an 11-day history of a gradually extending pruritic serpiginous tract on her right hand in June 2014. She expressed being a keen gardener and described noticing a 'bite' underneath her ring on her right little finger after handling compost in her garden in Surrey. When gardening, she generally used gloves of a thin material. Over the following days, a rash developed, tracking from the initial 'bite site' with a sensation of 'something crawling' under the skin. The patient later attempted to self-extract this with a sterile needle after which she noticed the lesion extending at an increased rate. The lesion was described as intensely itchy and was associated with significant sleep disturbance. There was previous travel of a 1-month trip to South Africa 4 months prior to presentation. There was no significant animal contact (including with cats or dogs); however, she mentioned her garden was surrounded by woodland and was regularly visited by deer, foxes and rabbits. Examination revealed an erythaematous papule between the fourth and fifth web space, with a red/brown elevated serpiginous tract tracking along the medial palmar aspect of the right hand (figure 1).

\section{Case 2}

A 50-year-old man presented, in August 2014, with a 4-week history of a small erythematous lesion on the dorsum of his foot, which gradually extended daily by a few millimetres (figure 2). The area was intensely pruritic and caused severe sleep disturbance. Antibacterials were prescribed by his general practitioner (GP), but with little effect. He

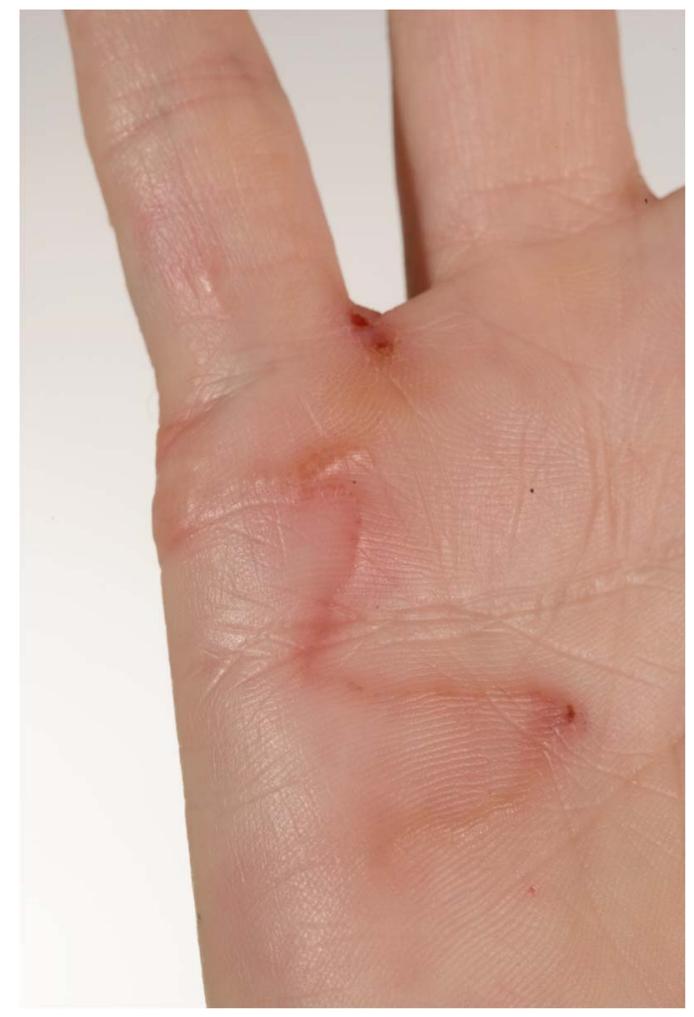

Figure 1 Serpiginous tract tracking from a small erythematous papule-the initial point of entry. A lesion is visible where the patient had attempted self-extraction of the larvae. 


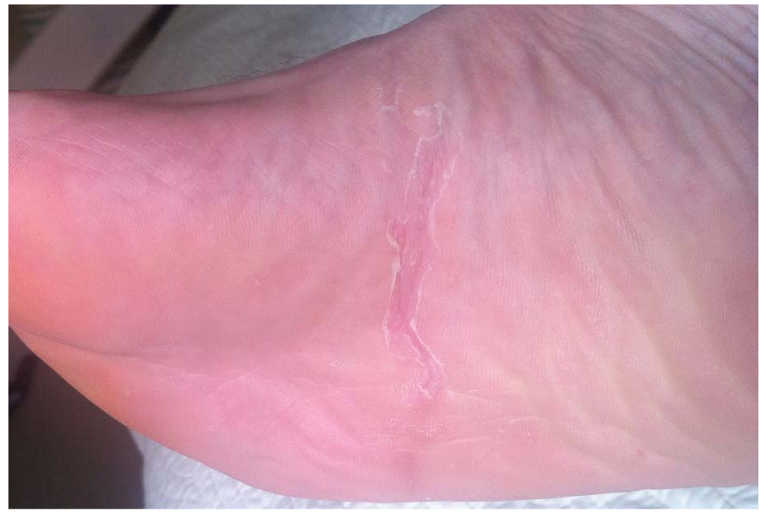

Figure 2 The healing serpiginous tract tracking from the dorsum onto the plantar surface of the right foot post a single dose of albendazole.

attempted to excise the track himself, and removed some white matter from within this, but symptoms continued and the track continued to elongate. Being a keen long distance runner, he regularly trained. He had recently been running on a particularly muddy path in the North Downs, which is well used by horse riders and dog walkers. He reported that it was usual for his lower legs to end up covered in mud when running. There was no significant history of travel abroad within the past 2 years, or other obvious significant contact. The diagnosis of HrCLM was made by a London GP.

\section{TREATMENT}

Both patients were systemically well and were given a single dose of albendazole $(400 \mathrm{mg})$ with resolution of the dermatitis after 1 week.

\section{OUTCOME AND FOLLOW-UP}

With this treatment regimen, early resolution of the lesion was achieved in our patients with no relapse reported within 3 months of follow-up.

\section{DISCUSSION}

HrCLM is commonly caused by infection with the larvae of the hookworms Ancylostoma caninum, Ancylostoma braziliense and, less commonly, Uncinaria stenocephala. ${ }^{1}$ The natural hosts of these hookworms are dogs and cats. Interestingly, both U. stenocephala and A. caninum have also been isolated from red foxes; ${ }^{2}$ in a study to quantify the prevalence of zoonotic-important parasites in the red fox (Vulpes vulpes) in Great Britain, U. stenocephala was isolated from the small intestine of $41.3 \%$ of the 588 carcasses collected. ${ }^{3}$ The risk of HrCLM in humans that is contributed by red foxes is yet to be ascertained. It is feasible that the cases described were due to skin contact with soil contaminated with infected dog/cat faeces; however, wild animals should not be discounted in the transmission of HrCLM.

Humans are incidentally infected when there is skin contact with contaminated soil or sand containing filariform larvae. These develop 5-10 days after the rhabditiform larvae have hatched from eggs passed in the faeces of their infected definitive host. ${ }^{4}$ Hatching and survival of the larvae are optimised in specific soil conditions: moisture, warmth and shade. For this reason, HrCLM commonly presents in tropical or subtropical climates. HrCLM in the UK is classically diagnosed in the returning traveller; however, cases acquired within the UK in addition to other temperate climates have been reported. Cases within the UK have been attributed to prolonged contact of clothing with infected dog or cat faeces, ${ }^{5}$ and from skin exposure to sand on a Cornish beach ${ }^{6}$ and grass on the west coast of Scotland. ${ }^{7}$ A further case in the UK has been reported following skin contact with faeces from puppies that had not received hookworm infection prophylaxis. ${ }^{8}$ Six cases in Italy occurred likely after contact with dog or cat faeces that had contaminated floral arranging material. ${ }^{9}$ Several cases that have presented in Germany, which has a similar climate to the UK, were deemed to be secondary to unusual weather conditions that is, a warm and humid summer, and contact with riverbanks and lakeside soil/sand. ${ }^{10-13}$ The UK, in 2014, had higher than average temperatures and rainfall over spring and summer. ${ }^{14} 15$ Our patients presented in June and August of that year. This, in addition to the contact with dark and moist areas of soil, likely increased the chance of transmission in our patients.

In our first case, there was a history of travel to South Africa 4 months prior to presentation. Prolonged incubation periods exceeding this time have been reported, however, an incubation time of a few days to a month is more common. ${ }^{16}{ }^{17} \mathrm{~A}$ study in Brazil reported that track length was significantly associated with the duration of the infection, with an average increase in length of $2.7 \mathrm{~mm}$ per day, ${ }^{18}$ thus time and place of exposure can be estimated. The length of the track in our first case was approximately $70 \mathrm{~mm}$, suggesting an incubation period of less than a month and hence the presumed location of acquisition to be the UK.

The diagnosis of HrCLM in the two cases we present is based on characteristic clinical findings. Diagnosis is largely clinical through the presence of a pruritic erythematous linear to serpiginous lesion extending from a red itchy papule-the site of larval penetration. ${ }^{1}$ The lesion is caused by an inflammatory reaction secondary to the migration of the larva through the epidermis. ${ }^{1}$ Lesions are mainly found on the most exposed areas of the body, that is, the upper and lower extremities and other areas that may come into contact with infected soil/sand, including the buttocks. Biopsy of the lesion followed by histological investigations rarely is of use, as the larva is located further than the visible lesions. ${ }^{6}$

\section{Learning points}

- While hookworm-related cutaneous larva migrans ( $\mathrm{HrCLM})$ is most likely to be seen in people returning from abroad, this may represent an emerging infection in the UK.

- The cases that we describe may be due to skin contact with soil contaminated with infected dog/cat faeces; however, wild animals should not be discounted in the transmission of HrCLM.

- The warm temperatures and higher rainfall experienced in 2014 may have had a positive effect on survival of the larvae and thus transmission in the two cases we have reported.

- Resolution of the lesion with no reported relapse within 3 months can be achieved with a single dose of oral albendazole.

- In the absence of a suggestive travel history, recognition by front-line physicians and, where appropriate, further communication with specialists, followed by efficient access to therapy, is essential in treating HrCLM transmitted in the UK. 
Although the eruption largely resolves after 2-8 weeks without therapy, for the relief of symptoms and reduction in the risk of recurrence and secondary bacterial infection, treatment with antihelminthic agents is recommended. ${ }^{17}$ However, the optimal treatment regimen remains controversial, with varying treatment durations of albendazole (1, 3, 5 and 7 days), a single dose of oral ivermectin or topical therapy with thiabendazole or albendazole being recommended in the literature. ${ }^{19-21}$ When comparing single dose regimens; higher cure rates with ivermectin $(81-100 \%)$ in comparison to albendazole $(46-100 \%)$ are reported. $^{20}{ }^{22}$ In more extensive or multiple lesions, a 7-day course of albendazole (100\% cure rate) has been advised. ${ }^{23}$ The optimum treatment regimen advised appears to be dependent on the extent of the clinical presentation. In our patients who presented with a single lesion uncomplicated by secondary bacterial infection, early resolution of the lesions was achieved with a single $400 \mathrm{mg}$ dose of albendazole, with no relapse within 3 months.

Competing interests None declared.

Patient consent Obtained.

Provenance and peer review Not commissioned; externally peer reviewed.

\section{REFERENCES}

1 Sunderkötter $\mathrm{C}$, von Stebut E, Schöfer $\mathrm{H}$, et al. S1 guideline diagnosis and therapy of cutaneous larva migrans (creeping disease). J Dtsch Dermatol Ges 2014;12:86-91.

2 Loos-Frank B, Zeyhle E. The intestinal helminths of the red fox and some other carnivores in Southwest Germany. Z Parasitenkd 1982;67:99-113.

3 Smith GC, Gangadharan B, Taylor Z, et al. Prevalence of zoonotic important parasites in the red fox (Vulpes vulpes) in Great Britain. Vet Parasitol 2003; 118:133-42.

4 CDC: Division of Parasitic Diseases and Malaria. Hook Worm. 2013. http://www. cdc.gov/dpdx/hookworm/index.html (accessed 20 Oct 2014).
5 Diba VC, Whitty CJ, Green T. Cutaneous larva migrans acquired in Britain. Clin Exp Dermatol 2004;29:555-6.

6 Roest MA, Ratnavel R. Cutaneous larva migrans contracted in England: a reminder. Clin Exp Dermatol 2001;26:389-90.

7 Beattie PE, Fleming CJ. Cutaneous larva migrans in the west coast of Scotland. Clin Exp Dermatol 2002;27:248-9.

8 Patterson CR, Kersey PJ. Cutaneous Larva migrans acquired in England. Clin Exp Dermatol 2003;28:671-2.

9 Galanti B, Fusco FM, Nardiello S. Outbreak of cutaneous larva migrans in Naples, southern Italy. Trans R Soc Trop Med Hyg 2002;96:491-2.

10 Müller-Stöver L, Richter J, Häussinger D. Cutataneous larve migrans (creeping eruption) acquired in Germany. Dtsch Med Wochenschr 2010;135:859-61.

11 Kienast A, Bialek R, Hoeger PH. Cutaneous larva migrans in northern Germany. Eur J Pediatr 2007;166:1183-5.

12 Herrmann A, Christoph T, Sebastian G. Larva migrans "saxoniae": larva migrans infection in Saxony. J Dtsch Dermatol Ges 2004;2:46-8.

13 Klose C, Mravak S, Geb M, et al. Autochthonous cutaneous larva migrans in Germany. Trop Med Int Health 1996;1:503-4.

14 Met Office. Met Office Summer 2014. 2014 (updated 14 September 2014). http:// www.metoffice.gov.uk/climate/uk/summaries/2014/summer

15 Met Office. Met Office Spring 2014. 2014 (updated 30 October 2014). http://www. metoffice.gov.uk/climate/uk/summaries/2014/spring

16 Siriez JY, Angoulvant F, Buffet $P$, et al. Individual variability of the cutaneous larva migrans (CLM) incubation period. Pediatr Dermatol 2010;27:211-12.

17 Hochedez P, Caumes E. Hookworm-related cutaneous larva migrans. J Travel Med 2007:14:326-33.

18 Jackson A, Heukelbach J, Calheiros CM, et al. A study in a community in Brazil in which cutaneous larva migrans is endemic. Clin Infect Dis 2006;43:e13-18.

19 Gill GV, Beeching NJ. Lecture notes on tropical medicine. In: Gill GV, Beeching NJ, eds. Cutaneous larva migrans. 5th edn. Oxford: Blackwell, 2004:284-5.

20 Caumes E. Treatment of cutaneous larva migrans. Clin Infect Dis 2000;30:811-14.

21 Sanguigni S, Marangi M, Teggi A, et al. Albendazole in the therapy of cutaneous larva migrans. Trans R Soc Trop Med Hyg 1990;84:831.

22 Vanhaecke C, Perignon A, Monsel G, et al. The efficacy of single dose ivermectin in the treatment of hookworm related cutaneous larva migrans varies depending on clinical presentation. J Eur Acad Dermatol Venereol 2014;28:655-7.

23 Veraldi S, Bottini S, Rizzitelli G, et al. One-week therapy with oral albendazole in hookworm-related cutaneous larva migrans: a retrospective study on 78 patients. J Dermatolog Treat 2012;23:189-91.

Copyright 2015 BMJ Publishing Group. All rights reserved. For permission to reuse any of this content visit

http://group.bmj.com/group/rights-licensing/permissions.

BMJ Case Report Fellows may re-use this article for personal use and teaching without any further permission.

Become a Fellow of BMJ Case Reports today and you can:

- Submit as many cases as you like

- Enjoy fast sympathetic peer review and rapid publication of accepted articles

- Access all the published articles

- Re-use any of the published material for personal use and teaching without further permission

For information on Institutional Fellowships contact consortiasales@bmjgroup.com

Visit casereports.bmj.com for more articles like this and to become a Fellow 